\title{
EL LUGAR DE LA SÁTIRA EN LA POÉTICA: LOS TRATADOS ESPAÑOLES DEL SIGLO XIX
}

\author{
FELIPE GONZÁlEZ AlCÁZAR \\ Universidad Complutense de Madrid \\ Fundación José Ortega y Gasset
}

\section{RESUMEN}

Se propone en este artículo investigar el género satírico y sus relaciones con la Poética a través de los tratados poético-retóricos de preceptiva españoles del siglo XIX. A lo largo de toda esa centuria la teoría literaria estuvo sujeta a grandes transformaciones, entre ellas, el triunfo de los principios hegelianos acerca de los géneros literarios. La sátira se enfrenta a esas mismas transformaciones y a su propia evolución: primero, identificada con la satura romana, y luego, a través de sus numerosas formas, convertida en un género mixto o de transición. Su lábil naturaleza parece enfrentarse directamente con la perennidad normativa de los tratados que, a pesar de la ruptura romántica, pueden considerarse herederos de los principios clasicistas.

Palabras clave: Tratados de preceptiva literaria, Sátira; Poética, Teoría literaria, Géneros literarios, Siglo XIX.

\section{THE ROLE OF SATIRE IN POETICS: THE SPANISH TREATISES OF THE 19TH CENTURY}

\begin{abstract}
This article aims to analyse the satirical genre and its connections with Poetics in the Spanish Poetry and Rhetoric precept treatises of the nineteenth century. Throughout that century, literary theory was subject to major changes, such as the success of Hegel's postulates on literary genres. Satire faces these changes and its own evolution: it was first identified with the Roman satura and afterwards through its various forms, it became a mixed or transitional genre. Its fragile nature seems to confront directly the normative perpetuity of treatises that, in spite of their rupture with romanticism, may be considered inheritors of the classicist principles.
\end{abstract}

Key words: Treatises on Literary precepts, Satire, Poetics, Literary theory, Literary genres, $19 \mathrm{TH}$ century.

«Los antiguos griegos no sólo inventaron todos los géneros de nuestra tradición literaria, sino que al crear sus primeros modelos orientaron de manera decisiva el curso de esa tradición. Está muy claro que la producción de esas obras pioneras, $[\ldots]$ precedió a todas las preceptivas literarias» ${ }^{1}$. Así pues, uno

\footnotetext{
${ }^{1}$ GARCÍA GUAL, Carlos. Historia, novela y tragedia. Madrid: Alianza, 2006, p. 7.
} 
de los motivos determinantes de los desajustes existentes entre los restrictivos catálogos de géneros de las poéticas y los más amplios testimonios literarios, reflejan una cierta minusvaloración de la Teoría literaria frente a la riqueza y variedad de la Literatura. El hecho de que, desde su origen aristotélico $^{2}$, uno de los mayores retos de la Poética haya sido la descripción y sistematización de los géneros, evidencia la raíz íntima del proceso especulativo de esta disciplina, cuya continuidad supera a todos los presupuestos arrumbadores del postestructuralismo.

La sátira refleja muy a las claras la determinación modelizadora, en tanto pretensión intelectual de primer orden de todos los teóricos desde la fundación de la Poética, por encajar de manera convincente a todos los géneros históricos dentro de sus nomenclaturas fuertemente dibujadas. Resulta muy aventurado, respecto de este género, adherirse por completo a cualquier respuesta, tanto para la definición, como para los rasgos descriptivos o su lugar en un sistema. No cabe ahora discernir si la sátira es un género histórico, una modalidad expresiva transgenérica, un modelo de discurso, un hecho intrínseco al carácter humano o incluso la parte más expansiva de un género natural que pudiéramos identificar como Didáctico-ensayístico, del que hay demasiados testimonios como para ser obviado. Podemos incluso estar de acuerdo con todas y cada una de esas respuestas y no caer en contradicción alguna, pues la historia de las investigaciones sobre la sátira así lo testimonia ${ }^{3}$. En

${ }^{2}$ Aceptando el aserto de Miguel Ángel Garrido en el estudio preliminar «Una vasta paráfrasis de Aristóteles» VV. AA., Teoría de los géneros literarios. GARRIDO GALLARDO, M. A. (Compil. de textos y Bibl. de). Madrid: ArcolLibros, 1988, pp. 9-27.

${ }^{3}$ No es momento de extenderse sobre esta cuestión. Por otro lado, en España carecemos de investigaciones en profundidad acerca de la sátira en un nivel especulativo o teórico, y dependemos de la exposición y explanación de autores extranjeros, sobre todo anglosajones y alemanes, que se han mostrado más activos y sugerentes. Como presentación del panorama histórico, y teórico a grandes rasgos, me permito apuntar sólo los siguientes textos: CORTÉS TOVAR, Rosario. Teoría de la sátira. Análisis de la «Apocolocyntosis» de Séneca. Cáceres: Universidad de Extremadura, 1986, pp. 17-125; PÉREZ LASHERAS, Antonio. Fustigat mores. Zaragoza: Universidad de Zaragoza, 1994 y CORONEL RAMOS, Marco Antonio. La sátira latina. Madrid: Síntesis, 2002. No obstante, hay últimamente un verdadero interés en estudiar aspectos puntuales en épocas o autores de la sátira en España; remito a ponencias y comunicaciones junto a compilaciones de artículos. Vid., por ejemplo, las actas publicadas de los congresos patrocinados por el Instituto de Estudios Humanísticos, también las del XIII Simposio de la Sociedad Española de Literatura General y Comparada. Estudios de Literatura Comparada. MARTÍNEZ FERNÁNDEZ, José Enrique, y otros (coords.). León: Universidad de León, 2002, pp. 233-448, o el reciente VV. AA., Estudios sobre la sátira española en el Siglo de Oro. VAÎ́LLO, Carlos y VALDÉS, Ramón (eds.). Madrid: Castalia, 2006. La sátira de Quevedo hace tiempo que ocupa la atención crítica y filológica con gran amplitud, incluso con un enlace en la página web del Instituto Cervantes dirigida por Lía Schwartz. La época justamente previa a la que analizamos en este artículo ha sido objeto de análisis en las obras de COUGHLIN, E. Teoría de la sátira en el siglo XVIII. Newark-Delaware: Juan de la Cuesta, 2002 y UZCANGA MEINECKE, F. Sátira en la Ilustración española. Madrid: Iberoamericana, 2005. Debo insistir en que no se trata de una bibliografía exhaustiva, sino orientadora. 
cualquier caso, como sugerimos al inicio, el mundo griego conoció diversos modos de sátira, de rasgos abiertamente satíricos traspasados a varios géneros como la comedia, y también de tipos de versos, originariamente los yambos. Si bien, en justicia, la famosa afirmación de Quintiliano («Satura quidem tota nostra est», en Institutio oratoria, X, I, 93), aun siendo una verdad a medias, se justifica plenamente por la medular contribución de Roma al género histórico de satura a través de Ennio, Lucilio, Varrón, y de los escritores mayores: Horacio, Persio y Juvenal ${ }^{4}$. La fortuna de la sátira en la didáctica clásica fue varia. Podemos confrontarlo a través de su presencia en la Epístola a los Pisones horaciana ${ }^{5}$ o en el tratado de Diomedes ${ }^{6}$, pero, en definitiva, se sometió a fluctuaciones en la nómina jerárquica que denotan tanto la complejidad intrínseca como la desmesura de límites que la definen. Al caminar sobre seguro, los preceptistas de la Antigüedad prefirieron ahondar en la identificación entre la forma regular satírica latina y la misma sátira, tratando de no detenerse en otros aspectos más perturbadores. No está de más recordar que la preceptiva retórico-poética pretende un estadio ácrono sobre los géneros, un lugar de imperturbable estatismo, intrínseco a su naturaleza. Sobre ese presupuesto se alza decisiva la perennidad de la jerarquía modélica de géneros históricos, cuyo ejemplo más logrado, la sátira regular latina de Horacio o de Juvenal, predica los caracteres que deben ser repetidos en toda composición de esa especie.

La crítica actual tiende a ver la sátira como un lugar de encuentro de rasgos satíricos: ironía, sarcasmo, crítica, pastiche o simple humorismo. Parece efecto natural, por la simple razón de que, hoy día, la sátira, género histórico concreto, casi ha desaparecido junto con la identificación con la moral superior a la que el satírico apelaba, que se compagina muy mal con las sociedades modernas ${ }^{7}$. El epigrama, todo tipo de poemas didácticos y el mismo poema satírico no participan de la práctica escrituraria general — tal vez en ámbitos no publicados tenga mayor fortuna-, junto a otros muchos subgéneros y for-

\footnotetext{
${ }^{4}$ Aceptando dos tradiciones: la sátira regular en verso, y la sátira menipea (con origen griego en Menipo), caracterizada por estar compuesta en verso y prosa. A la primera pertenecerían los grandes satíricos latinos y a la segunda, tanto griegos como romanos (Varrón, Séneca, Petronio, Luciano de Samosata o el emperador Juliano).

${ }^{5}$ Extraña la importancia desmesurada que se concede a la sátira frente a la tragedia o la comedia. El famoso tratado de los sátiros, tan extenso en relación a otros géneros, tiende a verse hoy como una excusa para tratar detenidamente el medular asunto del decoro. Vid. GARCÍA BERRIO, Antonio. Formación de la teoría literaria moderna. I. Madrid: Cupsa, 1977, pp. 205 y ss.

${ }^{6}$ Este gramático del siglo IV instituyó partes definitivas de la preceptiva satírica, desde su definición hasta los autores cuya tipología resalta: «Satura dicitur carmen apud Romanos nunc quidem maledicum et ad carpenda hominum vitia archaeae comoediae charactere compositum, quale scripserunt Lucilius et Horatius et Persius». Apud CORTÉS TOVAR, Rosario, op. cit., p. 19.

7 Vid. SCHOENTJIES, Pierre. La poética de la ironía. Madrid: Cátedra, 2001, pp. 183-185.
} 
mas métricas parece que irremisiblemente olvidados. La imperturbable naturaleza de ciertos cauces naturales de la comunicación humana hace imposible la pérdida de las virtudes específicas que adornaban a estas composiciones; por eso hoy tendemos a pensar más en lo satírico, que se corresponde con la capacidad de la sátira para impregnar todos los discursos saliendo airosa ${ }^{8}$, que en la sátira.

La Poética clasicista semeja un campo minado, más aún cuando el espíritu universalista de las Bellas Artes impone lo literario sobre lo restrictivamente poético ${ }^{9}$. El tránsito de la Antigüedad a la Modernidad, usualmente descrito en nuestra disciplina como el paso de las poéticas miméticas a las imaginativo-fantásticas, ofrece un campo de investigación muy apropiado para ahondar en los límites organizadores de los géneros literarios. Durante todo el siglo XIX la vieja Poética, revitalizada por un neoclasicismo que la fortaleció y sembró a la vez su disolución ${ }^{10}$, pervivió trasladándose, en un modelo único de supervivencia y eclecticismo, hacia el campo seguro de la moderna didáctica bajo su conversión en manuales de enseñanza de la Literatura. Su asombrosa riqueza numérica y su expansividad impiden ahora un mayor detenimiento ${ }^{11}$ y nos obligan a observar la presencia de la sátira en virtud de un factor radical. El tratado de géneros motiva un seminal impulso al mostrar abiertamente el esfuerzo por encajar toda forma poética en un sistema global y universal; en él reflejamos un intenso debate entre los géneros de la poesía y los de la literatura, en las fronteras internas que los definen y en la jerarquía que los condiciona.

Tal vez, desde nuestra perspectiva actual, sea la Preceptiva el espacio más contradictorio para investigar el lugar de un género que es más que un género, en un saber histórico pretendidamente antihistórico, y en el momento cenital de expansión y transformación del siglo XIX. La Preceptiva retórico-poé-

${ }^{8}$ Este fenómeno expansivo trae como paradójica consecuencia una diversidad formal, sin pérdida de sus rasgos fundamentales, que para muchos críticos constituye la verdadera forma de la sátira. Vid. FOWLER, Alastair. Kinds of literature. Oxford: Oxford University Press, 1982, p. 110.

9 Incluso en los tratados y manuales más evolucionados de finales de siglo, es obligada la tradicional división de los géneros literarios en su acepción extensa - lo escrito con intención estética- entre poéticos (líricos, épicos, dramáticos y mixtos o de transición), oratorios y doctrinales o históricos. Se afrontan así complejos límites entre verso y prosa, entre diferentes acepciones del concepto de literatura y de poesía y en la pertenencia de muchas obras literarias a uno u otro espacio clasificatorio. Es patente el influjo de esta división en la desubicación de la novela, a veces entre los géneros literario-históricos. Vid. mi artículo «Sistematización y utilidad pedagógica de los géneros literarios: la asimilación de la tríada hegeliana en la preceptiva española del siglo XIX», en Castilla, 28-29, 2003-2004, 111-130.

10 Vid. CHECA BELTRÁN, José. Razones del buen gusto. Madrid: CSIC, 1998, passim.

11 Debo remitir a dos libros para ilustrar esta cuestión con profundidad: ARADRA SÁNCHEZ, Rosa María. De la retórica a la teoría de la literatura. Murcia: Universidad de Murcia, 1997 y GONZÁLEZ ALCÁZAR, Felipe. Procesos de la poética clasicista. Murcia: Universidad de Murcia, 2005. 
tica es todavía un espacio de incertidumbres en algunos aspectos. La sátira, por su parte, necesita de un asedio desde todos los puntos de vista críticos relevantes. Y todavía el siglo XIX representa el nacimiento de la Modernidad teórico-literaria.

\section{PERVIVENCIAS CLASICISTAS}

Para la tratadística, en general ${ }^{12}$, la sátira se identificaba plenamente con los modelos clásicos latinos de la sátira regular. Entre las especies de poesías, junto a formas métricas y elementos de la Lírica, se dedicaba un espacio al epigrama y al poema satírico. Culminaban las referencias a la sátira con un mínimo detenimiento, según la profundidad del tratado, en la Comedia y en la Épica cómica o burlesca. Dichos géneros se acogían con mil reticencias debidas al decoro, que se acrecentaba sobre todo en cuestiones religiosas, y en la solemne prohibición de los ataques personales (parcere personis, dicere de vitiis). Circunstancialmente, se aconsejaba el uso del estilo familiar como apropiado y natural en estas composiciones. Además, era recomendable para los españoles que el poema satírico se escribiera en tercetos encadenados, por tradición de raíz italianizante.

Los autores fundamentales de estas primeras décadas del siglo XIX, Blair, Batteux y Hermosilla ${ }^{13}$, delimitan perfectamente el ideal clasicista preceptivo. Los dos primeros, en sus manuales españolizados, reconocen en la sátira un poema didáctico cuya forma tipificada correspondería con el prototipo horaciano. Por ejemplo, Blair comienza uniendo sátiras y epístolas, recomendando el uso de un estilo ligeramente más familiar al de los filósofos, casi en un tono conversacional. Rebusca el pasado de la sátira romana en la Come-

${ }^{12}$ Desde la recomposición de la Poética en el Renacimiento es notoria la influencia de idénticos autores y obras en la teoría literaria. Por ejemplo, a las puertas de nuestro estudio, el Cajón de sastre de Nipho (1. ${ }^{\mathrm{a}}$ ed. en 1760-61) dedicó su «cosido cuarto» del tomo II a hablar de la sátira. Para ello expuso declaradamente seguir la Ciclopaedia (1728) de Ephraim Chambers, y quizás sin pretenderlo volvió a volcar toda la doctrina sobre la sátira que había expuesto Julio César Escalígero en sus Poetices libri septem, [Lyon], apud Antonium Vicentium, 1561, origen de lo contenido en la llamada SATIRE de dicha enciclopedia. Remito a mi comunicación «Ideas sobre la sátira en el Cajón de sastre de Nipho», leída en Alcañiz en diciembre de 2003, en el Congreso Internacional Francisco Mariano Nipho. Lamentablemente no se han publicado actas.

13 MUNÁRRIZ, José Luis. Lecciones de Retórica y Bellas Letras, traducidas y acondicionadas a partir de original inglés de Hugo Blair. Madrid: Imprenta de Antonio Cruzado, 1798-1801, 4 vols. (citaré por 3. ${ }^{a}$ ed., Madrid: Ibarra, 1816-1817, 4 vols.); GARCÍA DE ARRIETA, Agustín. Principios filosóficos de la Literatura o Curso razonado de Bellas Letras y de Bellas Artes, obra escrita en francés por el Señor Abate Batteux... Madrid: Antonio de Sancha, 1797-1805, 9 vols.; GÓMEZ DE HERMOSILLA, José Mamerto. Arte de hablar en prosa y verso. Madrid: Imprenta Real, 1826, 2 vols. Blair publicó su Course en 1783, mientras que los Principes de Batteux vieron la luz entre 1746 y 1748. 
dia antigua, con su chocarrería y la mezcla de prosa y verso. Declara abiertamente que la forma actual se debe a Horacio, en el que predomina un tono medio empeñado en corregir costumbres. No falta, como es de rigor, el esquema tripartito de estilos satíricos encarnados en Horacio, Juvenal y Persio. El repaso de Munárriz a la Literatura española vadea a ciertos autores manifestándose a favor del decoro y en contra de las «indecencias» poco ejemplificadoras de Quevedo y su época ${ }^{14}$.

Por su parte, Batteux había elaborado un tratado más extenso, en el que podía permitirse exponer casi toda la tópica inherente a la sátira en las poéticas ${ }^{15}$. Primero la sitúa en un supragénero didáctico, cuya finalidad es la instrucción del lector. Repasa las diferentes formas de la sátira, de índole varia entre griegos y romanos. Busca un origen en el teatro heleno y de allí, a modo de canción dialogada, la supone trasladada a Roma ya con el nombre de $s a$ tura, traducido como canasta o bandeja de diversas frutas, y repasa la nómina conocida de los latinos desde Livio Andrónico hasta la famosa tríada ejemplar de la época imperial. Una vez presentada, la define como «una especie de poema, en el cual se ataca directamente a los vicios y extravagancias de los hombres». E incide en que se trata de un discurso en verso necesariamente, y mejor cuanto más breve - lo semeja a un retrato más que a un cuadro, queriendo decir tal vez de gran formato-, que, por su naturaleza agresiva o cuanto menos incisiva, precisa de una especial maestría en las cualidades del poeta a la manera horaciana: ingenio fecundo, aliento capaz de dar vida al poema y buen uso de la elocución poética. Lo que diferencia a la sátira de la actitud satírica presente en la Comedia es que los vicios se atacan directamente en la primera ( $«$ Se dirige directamente al hombre; tú eres, le dice: N. es un monstruo lleno de vicios»), si bien la gradación de esos mismos vicios criticados la inclinarán hacia actitudes cercanas a lo cómico o a lo trágico en una serie escalonada que refleja la variedad satírica desde el odio a la gracia a través de una gradación: sal, acrimonia, hiel. Por necesidad intrínseca, el satírico debe involucrarse en ese clima de doble envolvimiento, no contentándose con emitir un juicio moral, sino poseyendo «cierto germen de maldad encubierta» que disfraza con el velo de la virtud. Sobre lo cual previene: no hace mejores a los hombres. Reclama, pues, prudencia y cuidado a los lectores, ya que nos puede invadir el mismo espíritu malicioso. Sobre la forma en que puede aparecer este tipo de composiciones se muestra poco rígido: «Tan pronto es épica como dramática [...]. Unas veces lleva el nombre de discurso; otras el de epístola. Todas esas formas no son nada en el fondo. Cualquier

14 MUNÁRRIZ, José Luis, op. cit., vol. 4, pp. 10-13. El rechazo a Quevedo toma un tinte de modernidad neoclasicista, provocado por el desdén contra la corriente realista en la pintura de entresiglos: «...semejante a los pintores naturalistas que creen son más verdaderos cuanto más exactos», op. cit., p. 13. Aclaro que actualizaré la ortografía de los tratados para armonizar las citas con el español moderno.

15 GARCÍA DE ARRIETA, Agustín, op. cit., 1801, vol. V, pp. 242-310. 
escrito es satírico cuando se ve que es el espíritu de la Sátira quien le ha dictado». Esta capacidad cuasicamaleónica ha sido probablemente más determinante para la sátira que la indiferencia formal, genérico-histórica o incluso métrica, que la ha acompañado diacrónicamente ${ }^{16}$. Y muestra claramente uno de los espacios de fricción más sustantivos entre la perennidad de la Poética clasicista y el relativismo inducido por la ejemplificación histórica. De alguna manera Batteux debe de conciliar el repaso variopinto de las sátiras desde los grecolatinos hasta Boileau ${ }^{17}$.

Hermosilla, todavía hoy con un perfil demoledor de pedestre reglista, aparece sin embargo, como un organizador eficiente de la materia que trata. Distribuye los géneros según sus fines: entre los poemas directos reconoce a los líricos, didácticos y descriptivos. Evidentemente, los segundos tienen como fin primordial instruir, formar o enseñar, no siendo exclusivos otros; de ahí la colocación de la sátira, siempre dominada por el aspecto final de la moralidad que debe defenderse. No es, sin embargo, un género ajeno a ninguna época: «...ésta ha existido y debe existir, necesariamente, en todas las naciones civilizadas; porque está en la naturaleza del hombre observar, censurar y zaherir los vicios, y aun las debilidades de sus semejantes» ${ }^{18 .}$ Esa inclinación natural únicamente varía en la ejecución como reflejo de formas y épocas diversas. Ante esa casuística debemos entender que la sátira es «cualquier poema directo en que se censuren los crímenes, vicios o simples ridiculeces de los hombres». Ya que debe corregir las costumbres públicas y los errores, hablaremos de una censura seria, jocosa o media según la categoría de esos errores. Y como suele acudir al texto de Blair traducido, deduce de éste que es natural persuadir al futuro escritor de que pretenda un estilo medio, cordial, más centrado en lo doctrinal que en lo patético. La conciencia de crítico clasicista no le permite vislumbrar un debate sobre el realismo; no ignora que la sátira, en cuanto poema, tiene un corto recorrido. La sátira ${ }^{19}$ literaria, pa-

${ }^{16}$ Esa imposible delimitación de la sátira frente a la epopeya o la elegía, pongamos por caso, pese a existir actitudes épicas y elegíacas en novelas o poemas líricos, no basta para inducir a marcar diferencias entre sátira y satírico. De hecho, podemos concluir como Fowler que la variedad de forma es precisamente la forma fija de la sátira, cuya presencia basta para teñir cualquier texto. Vid. nota 8.

17 En un apéndice añadido a la traducción García de Arrieta (op. cit., pp. 310-351) añade un intento de historia de la sátira española en la que resalta los valores morales y elocutivos de algunas composiciones de Lupercio Leonardo de Argensola, de Jáuregui y de otros más cercanos, como Pitillas o Jovellanos. Toma con verdadero disgusto las composiciones quevedescas y otras similares por sus ataques al debido decoro. Es un fiel representante de la opción contenidista, incapaz de permitir que la moralidad afecte mínimamente a la función formativa de la Poética.

18 GÓMEZ DE HERMOSILLA, José Mamerto, op. cit., vol. II, p. 165. En adelante aludiré a este tratadista en la obra citada, vol. II, pp. 164-169.

${ }^{19}$ El uso continuado del término sátira puede resultar fatigoso pero necesario, toda vez que es preciso marcar las diferencias y delimitaciones entre sátira y otros términos aparen- 
ródica o solamente formativa, es más efectiva que la moral; y señala que el Quijote, en cuanto crítica de los libros de caballerías, consiguió acabar con esos modelos cuando ni toda la maestría de Horacio, Juvenal o Persio pudieron corregir en modo alguno las costumbres romanas.

La Poética clasicista, envuelta en la rigidez neoclásica, se ha preocupado a lo largo del tiempo por estabilizar un sistema de géneros que atienda a la pureza y a la jerarquía. No pudiendo ahora discutir hasta qué punto la tríada genérica supone una imposición romántica o un modo de expresión natural, lo cierto es que cualquiera de estos teóricos necesita especular sobre el lugar de la sátira en el esquema de géneros de prestigio jerárquico que pretenden potenciar. La tradición latina de la bucólica y la sátira, sobre todo, determinan la necesidad de buscar un acomodo entre las formas de la Lírica, casi nunca nombrada así sino a través de la nómina de formas métricas que la determinan (soneto, canción, oda...) ${ }^{20}$, o en una especie de cajón de sastre en el que se suman rasgos definitorios: mantienen la dualidad verso/prosa; son composiciones muy variadas en extensión, forma y voz; poseen modelos de gran relevancia, incluso en época reciente, como en la poesía descriptiva de Thompson... De alguna manera, la tendencia a una finalidad educativo-formativa se potencia en estos tratados bajo numerosos parámetros: desde la calidad intrínseca de ciertos géneros al predominio de lo decoroso, pasando por el arraigo del contenido de las obras literarias sobre el anclaje temático de la Filosofía moral al modo de las «Socraticae chartae...» en la epístola horaciana, o el mismo interés pedagógico de los tratados reconvertidos en manuales de estudio más que en espacios para especulación.

En general, la tópica satírica clasicista obvia numerosos escollos que desvirtúan las claras fronteras del esquema genérico; más pendientes de un enciclopedismo abarcador de diferentes épocas y textos que de promocionar una sistematización no lastrada por modelos impuestos y ya casi irrealizables en esos años. El clarísimo modelo horaciano, sobre todo, con sus generales aspiraciones de mesura y contención, opera como un espejo sobre el cual las deformantes realizaciones de Rabelais o Quevedo, o las expresiones de la literatura popular, simplemente reflejan sombras.

\section{MODERNIZACIÓN Y PROFESIONALIZACIÓN}

Entre los años cuarenta y los sesenta del siglo XIX, la preceptiva retóricopoética española experimenta un proceso complejo de adaptación hacia la

temente sinónimos como crítica, burla, invectiva... La bibliografía psicologista, que busca en la actitud satírica un modo de conducta universal, es por lo general reticente a esta consideración.

${ }^{20}$ CHECA BELTRÁN, José, op. cit., pp. 147-163. Para un estudio pormenorizado de los mismos problemas sobre los géneros en los preceptistas del siglo XIX que ahora sólo podemos tratar de manera epidérmica, remito a GONZÁLEZ ALCÁZAR, Felipe, art. cit., passim. 
conversión en manuales específicos controlados por unos programas oficiales; se transforma en textos de estudio, reglados por los diferentes ocupantes del Ministerio de Instrucción Pública, que sancionan la cantidad, los contenidos y el nivel educativo al que irán destinadas. Bajo el esquema de un tratado de retórica y poética subyacen específicamente los materiales tópicos de la clasicidad teórico-literaria. Significativamente atados a sus raíces, estos manuales, con mejor o peor fortuna, tendrán una misión específica: encajar la tópica heredada con elementos novedosos de la modernidad romántica ${ }^{21}$.

La tipología general de estos tratados supone una superposición de paradigmas, el moderno y el clasicista, sobre el patrón general de la preceptiva, cuya influencia presiona activamente en la permanencia de valores y formas de la doctrina tradicional. Así pues, la sátira ${ }^{22}$ continúa siendo un género atípico, de temática muy diversa, difícil de encajar junto a los demás por la evidente contradicción de superar los códigos internos de la Poética al no operar en ella criterios de verosimilitud o de imitación. El hecho de la fijación ejemplar en la satura romana obliga además a relacionarla siempre con la realidad que parece mostrar y censurar ${ }^{23}$.

Basten como muestra los manuales de Gil de Zárate y de Coll y Vehí ${ }^{24}$. El primero, más elemental pero determinante por modélico, se limita a encajar las composiciones satíricas entre los poemas didácticos con la pretensión de censurar vicios. Resalta particularmente la letrilla y el epigrama que identificados como poemas menores plantean un tono distinto del de la oda, altura que nunca superan ni en su triple manifestación de seria, jocosa y media.

${ }^{21}$ No utilizo Romanticismo como escuela, cuya contribución capital desaparecerá entre los años cuarenta y cincuenta, sino como nacimiento de la Modernidad, que en la teoría literaria se expresa bajo el radical signo del paso de las poéticas miméticas a las imaginativo-fantásticas. Bajo esa transformación surgen los motivos elementales de lo moderno: la pretensión de libertad, el antirretoricismo, el enfrentamiento contra la normativa reglista y el dirigismo, la originalidad del genio creador... Vid. GONZÁLEZ ALCÁZAR, Felipe. «Inspiración frente a normativa en los tratados de preceptiva españoles del siglo XIX». En Crítica Hispánica, XXVI, 1-2, 2004, 57-74.

22 J. Brummack, ha estudiado la presencia de la sátira (satura) entre el siglo XV y el XVIII, pero la particularidad de sus trabajos no puede ocultar que los primeros humanistas enfocaron sus reflexiones bajo la luz de la influencia de la tríada romana clásica de autores: la censura, la invectiva, la clase de moralidad defendida, el realismo en la fábula, el uso del tono familiar o estilo llano del sermo, el hexámetro... Apud CORTÉS TOVAR, Rosario, op. cit., pp. 78-79.

${ }^{23}$ No sólo la realidad, sino una realidad determinada de una época determinada y en una sociedad determinada. Los problemas de Roma entre el principado de Augusto y el siglo II se pretenden eternos, así como su escala de valores, traspasan el supuesto influjo de la moral cristiana a través del ideal de la Stoa. Vid. CASTILlo, Carmen, «Tópicos de la sátira romana». En Cuadernos de filología clásica. 1971, II, pp. 147-163.

${ }^{24}$ GIL DE ZÁRATE, Antonio. Principios generales de Retórica y Poética. 9. ${ }^{\mathrm{a}}$ ed. Madrid: Boix, 1842, (citaré por Madrid: Gaspar y Roig, 1862, pp. 210-212), y COLL Y VEHÍ, José. Elementos de Literatura. Madrid: Rivadeneira, 1856. 
El tratado de Coll, gran conocedor del mundo clásico y románico, experto latinista, mantiene la concepción romana de la sátira y bajo esta fijación esparce su presencia en referencias puntuales: cualidades de la elocución, estilos, formas genéricas diversas y el poema satírico propiamente dicho. Las dos primeras indicaciones obedecen a una voluntad de englobamiento del objeto literario en la macroestructura poético-retórica. Así pues, la honestidad (honestum) forma parte, junto a la claridad y la precisión, de las cualidades de la elocución y se ve afectada por las libertades que se toman los satirógrafos en virtud del fin moral que persiguen. El exceso en esta licencia condujo, a ojos de Coll, a lo escandaloso de muchas franquezas griegas y romanas, que no se consideraban adecuadas a la moral educativa decimonónica ${ }^{25}$. Por otro lado, la variedad estilística que describe el autor desborda a la tríada de genera elocutionis pero la sátira permanece anclada en ese estilo medio, entre el ornato ingenioso y familiar, en el que destaca el modo jocoso; como manifestación de agudeza del ingenio puede precisar de mayor libertad que el satírico, tildado de acre, mordaz y grave, y el humorístico - que asume lo irónico, y cuyo abuso se transformaría en escepticismo o mal du siècle-, debiendo huir de lo chocarrero y bufonesco, cuyos límites no se pueden traspa$\operatorname{sar}^{26}$. Breves menciones a la sátira acompañan, por otro lado, las descripciones de la nómina de formas poéticas que alojan temas satíricos, ya sea la oda anacreóntica, el epigrama o el poema burlesco, parodia de la epopeya ${ }^{27}$.

Coll no puede aportar un nivel de implicación sobre la sátira mayor que

${ }^{25}$ COLL Y VEHÍ, op. cit., p. 147. Estamos ante las virtutes elocutionis heredadas de Teofrasto; recordemos por otro lado que lo que preocupa a Coll es aquello que trasgrede el decoro establecido, por ello entraríamos en los defectos contra lo aptum, dentro de los vitia que afectan a dichas virtudes. Tampoco desdeñemos la división de las causas en cinco géneros a la manera de Quintiliano para congraciarse con el auditorio, lugar en que se encontraría el honestum.

${ }^{26}$ COLL Y VEHÍ, op. cit., p. 189. Es de destacar que nada dice de particular sobre ningún tropo o figura que se pueda identificar plenamente con el oficio del satirógrafo, exceptuando el asteísmo en su obligada misión de esconder una burla tras la delicadeza. Y nada dice tampoco respecto de la relación entre discurso epidíctico y sátira, a partir de la alternativa del elogio contra el vituperio, tan presente en muchos ejemplos literarios mostrativos. (Sobre esto, vid. GONZÁLEZ ALCÁZAR, Felipe. «Un modelo de discurso humanístico: la sátira guevariana en Menosprecio de corte y alabanza de aldea», (en prensa). En Actas del IV Congreso Internacional de Humanismo y Pervivencia del Mundo Clásico celebrado en Alcañiz, como es costumbre, 2005.

${ }^{27}$ El epigrama («pensamiento con intención satírica», pp. 256-257) destaca entre estas formas líricas y épicas por su cultivo en el mundo grecolatino. No olvidemos la revitalización de diversos esquemas métricos de tema satírico a través del epigrama cultivado por los griegos — su origen parece remontarse al siglo VII a. de C. como dístico elegíaco- que inundaron el mundo helenístico y romano, y cuya popularidad y vigencia a partir del Renacimiento, por la publicación y traducción latino-vulgar de la famosa Antología Griega, denotan su importancia en el desarrollo de la poesía satírica hasta el siglo XVIII. Vid. Poemas griegos de vino y burla. Antología Palatina, libro XI. ORTEGA VILLARO, Begoña (ed.). Madrid: AKAL, 2006. Marcial fue tanto un modelo posterior cuanto un ejemplo de esa influencia. 
el que le confiere su modelo normativo. En la nómina de géneros admite un tipo de poema didáctico cuyo propósito es la instrucción concluyendo que el conocimiento supera al placer poético hasta el punto de que algunos poemas líricos deben situarse en la esfera de lo didáctico; así pues, las letrillas y romances satíricos son sátiras por ser educativas ${ }^{28}$. Junto a poemas didascálicos, descriptivos, epístolas o fábulas, la sátira se anuncia como una «censura amarga o festiva de vicios». Para ese propósito puede tomar todo tipo de forma discursiva e infiltrarse en cualquier género, más acertadamente en la novela y en el drama ${ }^{29}$. La tópica delimita, sin embargo, tras este prometedor inicio, un rosario de conocimientos aplicados a la satura entre la idealización de los principios horacianos y la casuística que conlleva: no acepta el ataque personal ni la sátira licenciosa, promueve el uso de un «encubrimiento pudoroso» y del hexámetro (en nuestra tradición hispana, los tercetos y el verso libre). Adapta todo ejemplo a una doble vertiente delimitada entre la censura seria y la burla jocosa o chistosa, ya se ataquen vicios o crímenes deplorables, simples defectos o extravíos, pretendiendo identificar a Juvenal y a Horacio con esta dualidad.

En el anuncio de los nuevos tiempos los tratadistas habían vuelto la vista hacia un mundo que era irrecuperable y que justificaba el afán liberador del universo artístico. La perturbación que suponía para la perennidad poéticoretórica la simplificación relativista del historicismo les obligó a incluir en sus manuales un panorama histórico que permitiera estudiar el desarrollo y la evolución de las obras literarias. Por comodidad adaptativa éste se transformó en una breve historia de autores y obras para ejemplificar la doctrina sobre los géneros. Forzado así Coll a considerar en el mismo grado tanto las sátiras de Horacio como las de Quevedo, los Argensola, Boileau o Jovellanos, el estatuto satírico admitió en su seno una nómina de obras tan numerosa y heterogénea, sobre todo en su marco románico-medieval ${ }^{30}$, que no son de extrañar

28 «Dándose el nombre de poesía didáctica a la que tiene por fin directo instruir, esclavizando la poesía a la ciencia de un modo más o menos encubierto [...] Algunas composiciones de que se trató en la poesía lírica toman a veces un carácter enteramente didáctico. Las letrillas y romances satíricos deben considerarse como una rama de la sátira propiamente dicha, aunque bajo formas más libres y más poéticas». COLL Y VEHÍ, op. cit., p. 318. Sobre la sátira específicamente, ibidem, pp. 324-327.

${ }^{29}$ Nada explica Coll de estas atribuciones, añadamos por nuestra parte la larga tradición de comunidad entre el drama y la sátira desde el punto de vista horaciano en la Epístola a los Pisones a través de la Comedia Antigua griega, perpetuado por Diomedes y sus imitadores. En cuanto a la novela, atiende a criterios más modernos, confirmados por Frye o Bajtin, acerca de la menipea y la novela moderna en la esfera quijotesca de los autores británicos del siglo XVII y XVIII: Swift, Jones, Sterne... Sobre esto último, que favorece las tesis anglosajonas de la sátira como un modo de pensar, inspirado antropológicamente en las tesis psicologistas, vid. BLOOM, Edward y BLOOM, Lilian. Satire's persuasive voice. New York-London: Cornell University Press, 1979, pp. 21 y ss.

${ }^{30}$ Modélica, en este aspecto, nos parece la reseña que Otis H. Green, dedicó al clásico libro de Gilbert Highet, The Anatomy of Satire. Princeton: University Press, 1962, en la cual 
las exigencias mínimas del tratado de la sátira y la investigación parcial en este género al igual que también sucedió con otros, sobre todo cuando se consolidó el interés en la Edad Media y en aspectos folklóricos. A partir de un cierto psicologismo, los manuales afirman que el principio motor de la sátira es común a toda época y sociedad, y natural en el hombre como ataque y como defensa. Tal parece ser la consecuencia del libro de Rubió, y del suyo propio sobre este tema ${ }^{31}$.

El discurso de Coll entrevé un trasfondo sociológico para explicar la virulencia y la desmesura de la invectiva provenzal: enfrentamientos de castas, clases o sexos. La crueldad del sistema feudal era del mismo grado que su sátira, arma de papel en un momento vengativo y cruel. No le importa tanto admitir que la sátira no abarca sólo a la sátira latina, cuanto resaltar su presencia en toda época: «Y es tanto lo que la sátira prevalece en nuestros tiempos, que las escuelas y los partidos políticos, que por el espíritu de su doctrina deberían proscribirla, son los que más usan y abusan de su poder destructor y de sus desórdenes. Desde la Reforma hasta la Revolución, la sátira fue revolucionaria; ahora viste todos los trajes y todos los disfraces» ${ }^{32}$. En la batalla ejemplarizante de su labor académica no le preocupa minusvalorar el objeto de su estudio, en tanto producto de un ataque personal con escaso valor moral. Por otro lado, la sátira provenzal supera el esquema genérico de la satura, ya que lo invade todo: canción amorosa, tensó, complainte, panegírico... Para un espíritu clasicista y preocupado por la moral cristiana, en la historia satírica Coll debía encontrarse ante el debate irreversible de su complejidad y de su función purgativa. Con la contención del docere trata de poner puertas al campo libérrimo al que se enfrenta mediante el desdén a las clasificaciones externas o temáticas, para suscribir un modelo genético o histórico solamente orientado hacia un nivel personal y otro general, en los cuales distribuir las sátiras provenzales en personales (injurias, críticas al poder..), las que critican hechos históricos (sobre la bipolaridad guerra/paz), las dedicadas a todo un pueblo, y las que censuran inmoralidades y vicios de clases sociales o profesiones... Esa particularidad de ejemplos admite una focalización parcial que desdice su esquema universal genérico, sin preocuparle que significativamente sean las constantes de la sátira las que permiten establecer un marco de estudio determinado a través de la censura.

respondió a las dudas generadas por el autor con numerosos ejemplos de formas románicas cultas y populares, desde sermones, testamentos satíricos, debates, juicios burlescos... En «A Hispanist's thoughts on The Anatomy of Satire», Romance Philology, XVII-1, 1963, 123-133.

${ }^{31}$ Coll declara apoyarse en este libro en la edición que manejamos de los Elementos. Barcelona, Imprenta del Diario de Barcelona, 1868, $4^{\mathrm{a}}$ ed. Las referencias son COLL Y VEHÍ, José. La sátira provenzal. Discurso leído al claustro de la Universidad. Madrid: Rivadeneira, 1861 y RUBIO Y ORS, Joaquín. Apuntes para una historia de la sátira en algunos pueblos de la antigüedad y la Edad Media. Barcelona: Magriñá y Subirana, 1868.

${ }^{32}$ COLL, op. cit., p. 100. 
Rubió, instalado en una perspectiva de moralidad inculpatoria ${ }^{33}$ compartida pero más acusada que la de Coll, se debate sobre la premisa general de la universalidad de la sátira con raíz y motivación antropológica y no estrictamente literaria: «La sátira es un desahogo de la indignación con más o menos causa producida en ellas por el espectáculo de los vicios morales o sociales, de las miserias y ridiculeces — a juicio se entiende del que los satiriza-, de la humanidad...» ${ }^{34}$.

Basa su poder en el miedo del hombre al ridículo, no como norma general, ya que solamente existe ese ridículo en el modo de mirar y en la perversión mental del que busca el lado negativo de las cosas en cuyo afán todo ha sido ya burlado por su misma relatividad con ese espíritu de parodia que, instalado en una sociedad, es un síntoma de degradación en opinión de Goethe. Esa risa que conduce a la duda y al escepticismo puede superarse con la compasión del escritor, caso siempre ejemplificado con Cervantes ${ }^{35}$. Aún así, siempre quedará minusvalorada a causa de la mezquindad de la sátira frente a las altas pasiones o las grandes virtudes. Esa premisa induce a Rubió a desnaturalizar los aspectos literarios y a dar la razón a quienes objetaban un sentido subversivo al poder de la sátira: desde las representaciones pictóricas grotescas del arte antiguo, con Wright y Champfleury, a la gran variedad medieval (cantos simposiales, parodias goliardescas, poesía carnavalesca, didactismo...), pasando por la impiedad griega con sus dioses, la severidad romana frente a la corrupción de la Urbe o las representaciones en las artes plásticas reflejada en miniaturas, bestiarios o sillerías corales. Ciertamente, Rubió no desea implicarse en su complejidad genérica, prefiere asumir la satura como un ejemplo más de una actitud humana que, a pesar de ciertas motivaciones purgativas por el hecho de que sátira medieval influyó en la reforma de la Iglesia, confirma la tendencia hacia la extremosidad negativa del ser humano, deleitándose en una actitud inquisitiva o vituperadora por simple afán de invectiva. Niega su productividad a pesar de la multiplicidad de ejemplos que él mismo aduce y mezcla terminológicamente risa, burla, obras festivas, arte naïf, crítica, invectiva, ironía, comedia y drama satírico, el spoudogeleion de los griegos, manifestaciones folklóricas, parodias y la nivelación de culturas: el ideal clásico frente a lo báquico y carnavalesco, paganismo contra cristianismo o germanización tardo clásica... Todo eso amalgama un totum revolu-

${ }^{33}$ Más aún, declarándose un simple historiador que daba fe objetiva, sin verse inclinado al espíritu satírico inspirado por el «escarnio y la parodia», además de enfrentarse a la común opinión elevada de sus cultivadores que «la creen capaz de proporcionar elevadas enseñanzas morales y sociales». Prueba de su premisa es que siendo un género didáctico no han servido a nadie sus críticas a las costumbres, que le parecen mero adorno retórico. RUBIÓ Y ORS, op. cit., pp. 2-5 de sus Apuntes.

${ }^{34}$ RUBIÓ Y ORS. Apuntes para una historia..., op. cit., p. 5.

35 Resumo su estado de ánimo con esta frase: «¡Ay pues de los pueblos cuando prevalecen en ellos la eterna y envenenadora risa de los Demócritos!». Ibidem, p. 10. He parafraseado a Rubió entre las páginas 7-13 de sus Apuntes. 
tum que alejan a estos Apuntes de una verdadera historia del género para transformarse en un escrito militante contra actitudes nihilistas o devastadoras a lo largo del tiempo, peligrosamente visibles en los años sesenta decimonónicos a ojos de un católico conservador como Rubió. La batalla por el control frente a la desmesura y el desborde inherentes a este modo de escritura, marca radical de la actualidad y vigencia satírica desde sus primeras manifestaciones, le apremia a desconfiar: «ya que a fuerza de embriagarse en la duda habrá acabado por no tener fe en nada; ni confianza en los demás ni en sí mismo» ${ }^{36}$.

\section{INSTITUCIONALIZACIÓN DE LA TRÍADA GENÉRICA DE HEGEL}

La presencia de la simetría genérica tripartita —Lírica, Épica y Dramática- responde a la necesidad de los tratadistas españoles de atender al desafío de conciliar la materia poética grecolatina heredada con una nueva preocupación filosófica y legal. Si ya la preceptiva se sentía fracasada en su intento de presentar una reflexión coherente sobre la literatura contemporánea de cada momento histórico desde la inclusión de formas y géneros medievales, ahora ya ni siquiera se veía capacitada para teorizar libremente sobre la obra artística si no era a través de la conversión en manuales ordenados por las instituciones de un Estado. La homogeneización perfecta toma sentido con la profesionalización del hombre de letras, en este caso, transmutado en profesor cuyo esfuerzo iba dirigido a la creación de manuales para uso directo en el aula. Los programas oficiales desde los años cuarenta obligan a la división de los libros de texto de Literatura General en un capítulo sobre Estética, otro sobre Preceptiva y otro Analítico-crítico, posteriormente llamado Histórico. Sin abundar en detalles acerca de leyes y fechas concretas, lo cierto es que desde mediados de siglo, cristalizando nítidamente en los años sesenta, los tratados aparecen armónicamente volcados sobre un esquema tripartito estable: tres partes generales (filosófico-estética, preceptivo-normativa e histórica), tres géneros poéticos (épica, lírica y dramática)...; incluso las divisiones internas de apartados o subcapítulos debían clarificarse sobre la magia del tres ${ }^{37}$.

Se podría discutir entonces sobre la sinceridad del hegelianismo que adorna-

36 RUBIÓ Y ORS. Apuntes para una historia..., op. cit., p. 238. Me permito recordar que Rubió (1818-1899) fue, además de catedrático de Literatura española, un prolífico escritor y representante del romanticismo conservador, con un predominante protagonismo en la Renaixença.

${ }^{37}$ Elemento que forma parte de una tradición en el mundo occidental, ya sea en el saber retórico poético (véase LORENZO, Juan, «La magia del tres y su rendimiento en la poesía latina». En AAVV. De Roma al siglo XX-II. Madrid: UNED, 1996, 81-91) como en estructuras lingüísticas profundas de pensamiento (véase RAMOS DE LA TORRE, Luis. «Número tres, armonía triádica y salvación en Ortega y Gasset, Fray Luis de León, San Juan de la Cruz y Claudio Rodríguez». Revista de Estudios Orteguianos, 2004, 8/9, 149-184). 
ba a los legisladores, pero no sobre que resultaba un hecho natural al responder a una actitud profundamente arraigada en la enseñanza europea de esos años. La Poética llevaba años buscando una base filosófica que sustentara y diera forma a toda su reflexión, consciente de que la expresividad artística desbordaba los cánones clasicistas, comenzando por la hiperestesiada sensibilidad íntima, muy potenciada por escritores románticos. Tras proponer el Eclecticismo de Cousin, importando de Francia esa posible filosofía oficial, el Estado vuelve su vista hacia el conjunto de propuestas que definieron el Idealismo romántico, convergentes en la aceptación de un Idealismo hegeliano desactivado y fragmentado, otra propuesta capaz de conciliar el interés formativo con cierta modernidad innegable; además de alguna vaguedad muy fácil de llenar entre el «arte por el arte» y el bien moral como máximas aspiraciones.

Bajo estos parámetros, la Belleza como fin y medio de la obra artística superando a la vieja mímesis, se expande una doctrina de categorías expresivas trenzadas en escalonada precisión entre la cúspide de lo sublime y las que se sustentan por negación o por oposición a ella: entre lo feo, lo ridículo, lo risible... Del mismo modo que las más estrictas normativas retóricas podían distinguir entre estilos tenues, graves, lacónicos, familiares... Buscaríamos entonces una cobertura o una posible excusa estética para replantear la función de textos que forman parte de esa consideración global de lo satírico como lugar de encuentro de rasgos universales de la expresión crítica y sus múltiples grados y formas: risible, vulgar, festivo, ácido, caricaturesco, burlesco, paródico..., en virtud de su capacidad para presentar los vicios humanos ${ }^{38}$.

Una nueva visión general de la Literatura como manifestación de la Belleza por medio de la palabra ${ }^{39}$ debería de verse implicada con las categorías contenidas en ella. No obstante, a través de la presión del buen gusto neoclásico, lo feo y sus derivaciones —incluido lo cómico- se consideran ajenas a la naturaleza calológica ${ }^{40}$ y sólo habían de admitirse por oposición a la búsqueda de un ideal positivo ${ }^{41}$. Álvarez Espino, en su tratado, resume que lo feo

${ }^{38}$ Del mismo modo que a través de lord Kames y otros pensadores de la Ilustración, luego reasumidos por Kant, se incidían en «hechos y estados psicológicos» que mostraban modificaciones de lo bello [vid. CROCE, Benedetto. Estética como ciencia de la expresión y ligüística general. Maracena (Granada): Ágora, 1997, pp. 304 y ss.], fue posible estructurar su contrario en virtud de la misma gradación. Vid. ROSENKRANZ, Karl. Estética de lo feo. Madrid: Julio Ollero editor, 1992, passim.

${ }^{39}$ Desde el ascenso de la estética de la Belleza pierde sentido la tradicional definición de la Poética como arte imitativa, si bien la justificación técnica perdura en cierta manera. Vid. GONZÁlEZ ALCÁZAR, Felipe, op. cit., pp. 39-57.

${ }^{40}$ El nombre moderno para esta antiquísima idea que considera que lo bello es igualmente bueno y verdadero se atribuye a Gioberti y a Kant, con el término Kallo-logía. El Eclecticismo importado de Victor Cousin acabó por hacer más amplio este uso a través de su Curso de Filosofía sobre el fundamento de las ideas absolutas de lo Verdadero, lo Bello y lo Bueno, LOSADA, N. R. de (trad.). Madrid: Repullés, 1847.

${ }^{41}$ Escribe Juste: «Podemos, por lo tanto, concluir afirmando que, en realidad, no deben considerarse como grados de belleza propiamente dichos más que lo agradable, lo bonito y 
y lo ridículo son un fenómeno estético que actúa, en cuanto tal, por comparación, como reverso de lo bello a través de la risa. Las fuentes de las que emana son tan consustanciales al hombre como la libertad pero tan artificiales que no existe en la naturaleza algo semejante. Necesita de un elevado desarrollo intelectual, conculcante para apreciar el valor educativo de la risa ${ }^{42}$. Fernández Espino, por su parte, incide sobre el plano de la virtud, de tal manera que tanto lo feo como lo ridículo muestran un desorden moral que se torna menor en la plasmación artística dando lugar a tipos risibles e inofensivos como la pareja Quijote-Sancho o el arquetipo del viejo presumido, siendo ciertamente cómicos — de la comedia y su lema ridendo corrigo mores-, por tanto, relativamente dañinos ${ }^{43}$. Manuel de la Revilla, aun siguiendo al anterior, delimita más el campo en la estela (post)hegeliana de la contradicción entre lo que es y lo que debería ser, es decir, admitiendo que en lo feo hay una anomalía entre el fondo y la forma, ya que la natural pretensión de que el arte refleje belleza puede admitir un desorden pasajero que de manera consciente sólo puede producirse en dicha actividad artística. Esta afectación idealista resulta extremadamente opuesta a la naturalidad antropológica de la actitud satírica, invalidada cuando la intención de mostrar vicios y corregirlos encubre simplemente una actitud bufa o grotesca, exagerada, que ya no produce emoción estética ${ }^{44}$. Para finalizar los testimonios estéticos, Sánchez de Castro aclara la significación honda del hegelianismo, matizado y domesticado ${ }^{45}$ en idealismo moralizante, para el cual la fealdad es sólo una perturbación de las leyes naturales sobre las que lo cómico, a decir de Solger o Vischer, solamente muestra, como dijimos arriba, una contradicción entre fondo y forma. Se rompen las barreras valorativas en lo ridículo, de donde no pro-

quizás lo sublime; pues lo gracioso, lo elegante, lo delicado, majestuoso, grandioso, etc., son elementos o aspectos varios que la belleza puede ofrecer. Lo cómico no es bello en sí, y sólo puede serlo, bien porque su manifestación artística sea bella en virtud de lo medios de que el artista se valga para realizarla, bien porque presentándose en oposición con los elementos de belleza de la obra, contribuya a darla mayor realce o a llamar más especialmente la atención sobre aquellos.» JUSTE E ISABA, Pedro. Literatura General. Madrid: Tipografía Reina, 1895, I, p. 84.

42 ÁLVAREZ ESPINO, Romualdo y GÓNGORA FERNÁNDEZ, Antonio. Elementos de literatura filosófica, preceptiva e histórico-crítica con aplicación a la española. Cádiz: Imprenta y Litografía de la Revista Médica, 1870, pp. 88-97.

${ }^{43}$ FERNÁNDEZ ESPINO, José María. Elementos de Literatura General. Sevilla: Librería de la calle de las Sierpes, 1871, pp. 80-83.

${ }^{44}$ REVILlA, Manuel de la y ALCÁNTARA GARCÍA, Pedro. Principios de Literatura

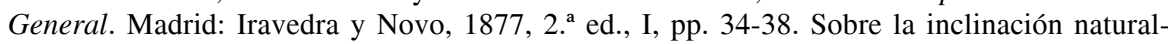
antropológica del ser humano a satirizar, véase el ya clásico HODGART, Matthew. La sátira. Madrid: Guadarrama, 1969, passim.

${ }^{45}$ Queremos decir, convertido en una mera plantilla o un modelo que responde a unas necesidades descriptivas de géneros históricos y no un sistema de actividad y progreso, de connatural dinamismo. Vid. SZONDI, P. Poética y filosofía de la historia I. Madrid: Visor, 1992, p. 278. 
viene más que un placer sensible, triste, ya ausente de belleza por su imperfección moral. No es de extrañar la confraternización con el Platón rígido que expulsaba a los poetas cómicos por inadecuados a la naturaleza e impropios del arte ${ }^{46}$.

Limitada la validez de la sátira a los géneros tradicionales, anulada la intencionalidad placentera del moderno lenguaje satírico, que era lo que en realidad había celebrado el Romanticismo alemán a través sus reflexiones sobre el humor, la agudeza o la parodia ${ }^{47}$, incluso desdibujada la tradición poéticoretórica del ridiculum tradicional, sólo quedaba la plasmación del sistema genérico de Hegel para atender a una ordenada colocación y valoración específica de autores, modelos y obras, tal vez de estilos, desde la descompensación de la causa final hacia el docere haciendo innecesario toda justificación de un ataque purgativo o corrector. Pese a tal, la natural inclinación al presupuesto filosófico-estético de la nueva Poética perturbaba la estabilidad de los géneros aceptados por el sistema clasicista ya que Hegel no trata en su Estética a la sátira como un género, sino como un medio expresivo, un propósito intencional que permitiría acogerse a la modernidad conceptual ${ }^{48}$. La lectura del sistema desactivado del filósofo alemán hurta que a su parecer la sátira se identifica con una forma de transición para explicar la transformación profunda entre el arte clásico y el romántico a partir de la conversión de algunas formas clásicas en simbólicas. En virtud, un proceso en el que necesariamente interviene el subjetivismo en el arte romántico para alcanzar la superación de lo sensible en donde, como anticipó Schiller, la sátira se aparece para manifestar el contraste entre la manifestación perfecta de la idea (ideal del arte clásico) y la forma corporal sensible (mundo real) ${ }^{49}$. En ese conflicto el hombre que no puede gozar de la plenitud de la vida por su enfrentamiento con un mundo corrompido se enclaustra reflexivamente y expresa ese drama con prosaísmo exento de belleza: ni es poema épico, ni lírico, es «humor disgustado, [...]. Ni produce verdadera poesía ni obra de arte verdadera. Así la forma satírica no puede ser considerada como un género particular de poesía; sino que mirada de un modo general, es la forma de transición que termina el arte clásico» ${ }^{50}$. Su propio análisis histórico se lastra de esta concepción. Por tanto, reconoce Hegel en la sátira una actitud meramente romana en cuanto poe-

${ }^{46}$ SÁNCHEZ DE CASTRO, Francisco. Lecciones de Literatura General y Española. Madrid: Imprenta de San José, 1887, pp. 76-83.

${ }^{47}$ Por ejemplo, en BELTRÁN ALMERÍA, Luis. La imaginación literaria. La seriedad y la risa en la literatura occidental. S.1.: Montesinos (D. L.), 2002, pp. 224-234.

${ }^{48}$ Como dijimos al comienzo, la sátira se tiene hoy por un lugar de encuentro y un proceder determinado para la crítica y no solamente un género histórico. Más que un modelo fijado se pretende un proceso intencional, un modo de escribir que inunda cualquier obra literaria. Vid. PEALE, George C. «La sátira y sus principios organizadores». Prohemio, IV, 1-2, 1973, 189-210.

${ }^{49}$ HEGEL, G. W. F. Estética. Barcelona: Alta Fulla, 1988, I, p. 202.

${ }^{50}$ HEGEL, G. W. F., op. cit., I, p. 203. 
ma didáctico, con su espíritu rígido y dirigido a la abstracción, contrario al arte verdadero. Y mediatizado además por su fin moral, al que adorna con las virtudes externas del metro, de las imágenes o de una retórica elegante: «El disgusto que inspira a la virtud el espectáculo del mundo, tal es el sentimiento que trata de expresarse muchas veces en declamaciones vacías» ${ }^{51}$. Una forma tan alejada del momento en que escribe estas palabras que había casi desaparecido, conscientes, creadores y críticos, de que aquella exigencia de firmeza estaba en contradicción con el mundo que habitaban en el Ochocientos.

La mayoría de los rasgos descritos en la Estética van a ocupar un espacio privilegiado en el análisis de la sátira hasta hoy ${ }^{52}$, pero fueron en su momento interpretados de manera restrictiva. Ya Coll, en su repaso a la sátira provenzal dejó filtrar numerosas ideas hegelianas, pero acabando por enfrentarse a la centralidad de la negación del género y a la imposibilidad de su existencia en aquella circunstancia histórica. Y puntualiza: la sátira no es sólo romana sino universal y presente en toda época; el contraste real-ideal provoca una distinción entre la aplicación de los principios abstractos racionales y la mera presentación de un cuadro costumbrista de errores y vicios que se destruyen por sí mismos en lo meramente cómico. Por fin, la no adscripción de la sátira a un género poético le parece a Coll imposible de aceptar, ya que en su propia esencia radica la censura amarga o festiva de errores y vicios, sea cual fuere el medio adoptado para ello ${ }^{53}$.

El muy hegeliano ${ }^{54}$ manual de Canalejas ${ }^{55}$ presenta un ejemplo modélico de la incidencia de las ideas del filósofo prusiano y de su uso interesado a

${ }^{51}$ HEGEL, G. W. F., op. cit., I, p. 204. Y sigue: «Este forma de arte, prosaica en sí misma, no puede llegar a ser poética sino cuando nos pone a la vista la imagen de una sociedad corrompida que se destruye con sus propias manos. [...]. Encontramos en él [Horacio] un modelo de burla fina y de buen gusto; pero no en igual grado la verdadera alegría poética que se contenta con poner en ridículo lo que es malo. En otros, por el contrario, la sátira es sólo un paralelo, un contraste entre el vicio y la virtud.»

52 PÉREZ LASHERAS, op. cit., p. 117.

53 COLL Y VEHÍ, José, op. cit., pp. 98-99. Más curioso es el argumento empleado para superar la exageración del filósofo alemán, «hija del espíritu sistemático que frecuentemente le extravía»: si aceptara esa premisa no existiría la sátira provenzal a la que dedica su libro. Es lugar común desconfiar de la restricción de Hegel sobre la sátira en tanto eminente y exclusivamente romana, como se repite en Rubió y en muchos tratadistas posteriores.

${ }^{54}$ No he querido incidir en la transmisión de textos filosóficos. Me permito recordar que a muchos se los leía a través de traducciones francesas, también tardías, o simplemente por fuentes secundarias en manuales universitarios plagados de definiciones y meras particiones generales. Las Lecciones de Estética, en particular, no se tradujeron al español hasta 1908 sobre la segunda edición francesa (1874) de la traducción de Benard por Hermenegildo Giner de los Ríos (Madrid: Daniel Jorro, 2 vols.). Es el texto que yo he seguido en edición facsimilar por su mayor cercanía al proceso que narramos.

55 CANALEJAS Y CASAS, Francisco de Paula. Curso de Literatura General, I. La Poesía y la palabra. Madrid: Diario La Reforma, 1868 y II. La Poesía y sus géneros. Madrid: Minuesa, 1869. 
modo de estructura paradigmática para volcar entera la tópica genérica clasicista en un modelo pretendidamente novedoso y de una rectitud formal consecuentemente estética. Al repasar los géneros de transición entre la Épica y la Lírica, tras la Elegía, Canalejas debe detenerse a explicar detalladamente la Sátira ${ }^{56}$, discrepando de su origen romano a favor de la universalidad antropológica. La verdadera afirmación de Quintiliano, propia de un retórico, se basa en el hecho de haber dado forma, incluso métrica, a este modo expresivo mediante la utilización de elementos de la poesía popular que fueron perfeccionados de acuerdo con la medida versal latina ${ }^{57}$. En particular, el poder satírico consiste en la expresión del sentimiento de lo cómico, a través del cual ponemos en relación esta intención con los géneros naturales: la épica burlesca, el drama satírico y el propio género de transición llamado Sátira. Incide Canalejas en el origen alemán de sus premisas con la consideración de que estos poemas denotan un contraste señalado y una oposición entre lo objetivo y lo subjetivo. Ese contraste entre la visión épica y el interiorismo lírico opera en el juicio del poeta en cuya fantasía se aloja emotivamente, hasta tal punto de que ahí, en esa indefinición, se manifiesta la pura esencialidad satírica. Más aún, ya sabido a través de Schiller, Hegel o su seguidor Vischer, un poeta satírico es el que «toma por asunto la distancia que existe entre las cosas tales como se dan en el mundo y como son, o sea, el contraste que existe entre lo real y lo ideal». Y aquí surge el verdadero espíritu del sistema dinámico hegeliano, ya que la sátira se encuentra en las grandes transiciones del arte destruyendo el ideal que había animado éste en su esplendor: tanto el Renacimiento sobre la Edad Media como el Romanticismo desde lo Neoclásico. Esta pugna es el resultado de un enfrentamiento social en que lo individual lucha contra lo común y ante esos cambios impulsados por el subjetivismo «brotan la ironía, la amargura, la desesperación, la cólera, la ira, y por lo tanto, la invectiva, el ultraje, el sarcasmo y aun la blasfemia...». Canalejas piensa en la legitimidad del estatus del poeta que lucha contra su tiempo en todo lo creído y amado por su edad si está impulsado por un fin moral y que sueña con algún estado ideal y perfecto, sumo, sin contradicciones, al que el espíritu humano aspire bajo especie de belleza absoluta y perfecta. En abierta oposición a Hegel, «el género satírico debe ser estimado como miembro vivo y miembro interesante del organismo de la poesía». Y tiene que ser la crítica,

56 CANALEJAS Y CASAS. Curso de Literatura General. II. La Poesía y sus géneros, op. cit., pp. 335-365.

57 De ahí su conversión en composiciones diversas y el propio nombre de Satura-Satur, aludiendo a esta consignada variedad. Tal vez tenga mucho que ver tal afirmación general con la procedencia de la bibliografía declarada por el autor consistente en manuales franceses e italianos (Lefranc, Ranalli, Gravina, La Harpe, Carrière, De Robiano...), la Historia literaria española de Friedrich Schlegel, los Apuntes de Rubió, el tratado de Milá (Principios de teoría estética y literaria), incluso el famoso ensayo seminal del Romanticismo europeo de Madame De Staël (De la Literatura) y el tratado de métrica latina de Patin. 
con las condiciones estéticas que deben constituirla, la responsable de corregir los extravíos de la sátira; pide que se analice por medio del gusto público, del mismo modo en que los autores cultos transforman las invectivas o chanzas de la poesía popular según el gusto decoroso de las clases altas ${ }^{58}$ que puede hacerse presente enfrentando a la «grotesca poesía popular de la Edad Media» con la más evolucionada estéticamente de los siglos áureos.

Como consecuencia de ser la sátira una expresión de la individualidad en lucha con el ideal común, nos inclinaríamos con Canalejas a ver en ella un género didáctico, como juzgan los tratadistas, que pudiera influir en la educación y en la enmienda cultural y moral. Pero no es tendencia natural en los géneros poéticos el didactismo moral, y en este caso tanto da que refleje esa finalidad cuando a la vez critica, censura, disuade, persuade, y afirma o niega. Incluso es capaz de mostrar todos los niveles de la subjetividad lírica, y contenerlos todos a la vez, dada su amplitud de intereses. Así como la Elegía expresa dependencia, la Sátira expresa contrariedad, lucha y oposición; si una causa dolor o tristeza, la otra despierta en el alma sentimientos apasionados «censurando la realidad que pinta con los colores más propios para mostrar su disparidad con lo ideal».

Canalejas, como antes hicieron sus predecesores, debe ahora conducir sus argumentos hacia una clasificación compleja por la universalidad y variedad de pasiones humanas que refleja: «...[baste] saber que la Sátira es el género artístico que expresa la belleza que se manifiesta en la contraposición y lucha entre lo común o general, y lo individual o subjetivo, empleando el metro que mejor responda a la energía y vivacidad de las emociones del ánimo». Además, permanece demasiado apegada a la tradición poética de los tres grandes satirógrafos latinos y, en consecuencia, de la propia satura.

Esta propuesta, pretendidamente moderna y cercana a las últimas manifestaciones de la ciencia estética, proclive a reconocer la libertad humana en la producción de bellezas artísticas, se enfrenta a la fijación de tipos invariables y de «modelos fijos y constantes para el cultivo de un género literario». En su opinión, se debe atender a dos únicos factores: el predominio de elementos épicos o líricos, y la mayor o menor extensión e intensidad que se revela en el uso satírico. En el primer caso, Canalejas se esfuerza por respetar el esquema genérico de Hegel, todavía no demasiado entumecido. Tal causa trae consigo el principio dinámico que vertebraba todo aquel sistema: cuál es el

58 Usa además el adjetivo de urbano, lo cual remite contraria pero etimológicamente a ese acusado contraste de la satura romana entre las insidias e incomodidades de la Urbs (no otra que Roma) y la tranquilidad de la vida campesina idealizada del pequeño propietario. Sociológicamente, aparte del ideal de la Stoa al que aludíamos arriba, cabe también parar a pensar en la pura historia de Roma y el momento trágico de los últimos años de la República, con sus crímenes, proscripciones, alejamientos y los repartos forzosos de tierras entre los veteranos del ejército. No cabe duda de que a sus ojos, el origen de todos los males provenía de un lugar determinado frente a otro, invadiéndolo. 
origen de los géneros históricos en las tres áreas fundamentales. Y éste acaba delimitado con vaguedad al estar emparentada la sátira a la vez con la épica, a través de la parodia, el poema satírico y el poema burlesco, y con la lírica, y expresarse tal parentesco en los grados de su presencia en diferentes composiciones. No obstante, la modernidad parece haberse inclinado hacia el predominio de lo subjetivo-lírico envuelto en la capa del libérrimo humour, cuyo estilo se manifiesta por la espontaneidad antirretórica del discurso en la «vivacidad del ingenio, realizada en transiciones rápidas y bruscas, que contradigan la permanencia de un juicio y de una norma, ya en el sujeto, ya en el objeto». Contra la tendencia a considerar este estilo una innovación anglosajona o germánica, manifiesta, según este Curso, una actitud universal y perenne en la raza humana: el humorismo de Swift o Heine contiene el mismo espíritu burlón de Boyardo o Berni. La variedad del humor y sus grados son únicamente variedades del elemento estético de lo cómico y, por tanto, modos de expresión de lo satírico ${ }^{59}$. De igual manera procede con la ironía. De manera un tanto sorprendente, toda la actualidad y la complejidad de este tratado deviene en pura tradición del elemento formativo, del docere que ha mantenido inalterable su presencia censora en la Poética clasicista. Estos modos y variedades, adornados por su libertad y espontaneidad, firmemente asentados en la conciencia del Moderno hasta hoy, se encauzan bajo formas menores de lo satírico sobre el que sigue pendiendo la desconfianza moralizante y un cierto descrédito del propio valor literario ${ }^{60}$. En un último giro sorprendente, el áspero estilo de Juvenal deviene, a su juicio, más auténtico que las desconsoladas expresiones del género humorístico, privadas en su vacío existencial de una verdadera condición estética y señaladas como hueros ejercicios de escuela: «Sólo en cuanto sea real lo expresado, es bello; pero es digno de gran censura cuando degenera en un pobre ejercicio retórico, tanto más fútil, cuanto más debe campear en él la espontaneidad, que muchos confunden con la voluntariedad del ingenio exhausto y vulgar» ${ }^{61}$.

59 «... ya indicó Hegel que ni es tanta su importancia ni tanta su influencia en el arte, y añadimos que el humor, la ironía, el chiste y el gracejo, la melancolía irónica (la laune de los alemanes) no son más que meras variedades de lo cómico y más determinadamente, modos de expresión de lo satírico.» En CANALEJAS Y CASAS. Curso de Literatura General. II, p. 353.

${ }^{60}$ «...; y por último, es cosa que no requiere ni dotes de ingenio ni cualidades de sensibilidad, seguir el caprichoso giro de una fantasía soñolienta, pasando de lo trágico a lo cómico, de lo burlesco a lo épico, de la frivolidad al sentido filosófico y profundo, mostrándose agudo, irónico, ingenioso a vueltas de místico y apasionado,...» Ibidem, p. 355.

${ }^{61}$ Más claramente expresado: «Esta producción inconsciente, en la cual el espíritu poético fluye del alma del escritor, sin la concreción y la severidad de concepto de que es propia toda determinación del ideal y de toda verdadera concepción, separa fácilmente a la poesía de su destino, que es la realización de la belleza, y la arrastra a lo trivial y a lo vulgar, o bien a un puro discreteo de conceptos fútiles y juegos de palabras impropios de toda realización de la belleza, de toda manifestación del ideal concebido por el hombre.» Ibidem. 
Respecto del segundo criterio de clasificación, Canalejas se permite usarlo de excusa para presentar un panorama histórico ejemplificador de la inmensa variedad de lo satírico en todas sus formas y metros: poema, chiste, donaire, letrillas satíricas, epigramas, épica burlesca...; en los tres géneros, incluido el drama, y en todas las culturas y momentos de la historia literaria, a excepción — hegeliana - de las manifestaciones de la cultura oriental. La diacronía de variedades y gradaciones de lo satírico se enfrenta a los mismos principios del sistema genérico, por cuya causa la sátira menipea, en cuanto combinación híbrida de elementos «poéticos y prosaicos», formalmente verso y prosa, y más rígidamente aún en la tradición más restringida del modelo vigente de géneros poéticos frente a literarios, queda relegada y excluida.

Finalmente, a manera de yuxtaposición de rasgos, se atreve nuestro tratadista a definir: «es la Poesía satírica una determinación en forma sensible de la belleza, que existe en la relación de contrariedad y oposición entre la objetividad y el espíritu subjetivo del artista, manifestada en la variedad de la palabra rítmica». Destacando después, como elemento fundamental, que la relación subjetivo-objetivo propia de todos los géneros de transición, se expresa aquí no como una dependencia, sino como una verdadera oposición que excita las emociones del espíritu para que el elemento subjetivo se sobreponga a su contrario. En tal enfrentamiento bipolar debe radicar la verdadera excelencia satírica.

El ejemplo de este manual, en intensidad y riqueza expositiva, es raramente imitado. Sin embargo, el modelo general de principios estéticos y de triunfo del esquema genérico heredado de Hegel toma consistencia en los numerosísimos tratados que aparecerán hasta fines de siglo. Incluso de manera más rígida y radical, escribiéndose respaldados por el prestigio de los seguidores del filósofo y su triunfo académico en toda Europa. Por otro lado, tal esquema permitía no sólo acoger de igual manera un proceso de clasificación cercano a la totalidad de manifestaciones literarias en cuyos elementos de transición podemos incluir todo tipo de obras no canónicas, sino también, como hizo el propio Hegel, la perennidad de la tópica y los modelos grecolatinos.

Sería el caso de los Principios de Salvador Arpa ${ }^{62}$, cuya doctrina general técnica en este punto se identifica con tantos otros manuales en cuanto a la diversidad de metro, la libertad y precauciones morales... Sobre el lugar de la sátira en el sistema genérico, persiste el mismo orden de tránsito desde la objetividad a la subjetividad a manera de discordancia y rebelión al darse cuenta el hombre de su inferioridad frente a la belleza objetiva encarnada en la elegía y oponerse a ella queriendo destruirla o alterarla. Llevados de este planteamiento casi pensaríamos en un origen psicofisiológico de la sátira endémico al ser humano, como parte de distintos grados de belleza que se ex-

${ }^{62}$ ARPA Y LÓPEZ, Salvador. Principios de Literatura General. Cádiz: Imprenta de la Revista Médica, 1844, pp. 270-272. 
presan de manera natural, remedando la oposición satírica a la belleza que se infiere de la Estética del profesor de Jenna. Demasiada convergencias, incluida la tradición doctrinal, se advierten en tratados del mismo origen: López Bastarán, Espantaleón, Milego... ${ }^{63} \mathrm{Ni}$ siquiera en Manuel de la Revilla, con un prometedor comienzo apelando a una manifestación estético-cómica de la crítica, leemos algo innovador aparte de la mayor o menor capacidad expositiva y la búsqueda frecuente de una fórmula feliz de definición: «... manifestación artística de la oposición entre realidad objetiva y la conciencia del poeta, traducida por éste en censura o mofa de dicha realidad» ${ }^{64}$.

Similar trato recibe la sátira en autores menos cercanos al hegelianismo y más a un esquema influido por la propia naturaleza clasicista del modelo preceptivo: los Ortega, Campillo... ${ }^{65} \mathrm{Si}$ en los manuales más imbuidos del espíritu estético-filosófico se hace hincapié en el lugar de transición de la sátira, éstos suelen preferir referirse a ella como perteneciente a un género mixto de mayor tradición preceptiva, casi siempre censurable por oposición a la integridad genérica del sistema triádico fijo. En algún caso, aun repitiendo las fórmulas felices del hegelianismo — contraste entre objetividad y subjetividad, multiplicidad de formas, invasión de todos los géneros y épocas- junto a las prevenciones tradicionales — moralidad, censura, idealismo intencional del poeta, corrección de vicios, asociación a épocas de decadencia-, se es consciente de la endeblez situacional de la sátira en un sistema cerrado y estático, en una plantilla fija en la que todo género de prestigio ha encontrado acomodo. De ahí las vacilaciones nominales de estatus entre mixto, de transición, secundario ${ }^{66}$ o complejo ${ }^{67}$, similar al de la elegía, la bucólica, las epístolas o la misma novela, géneros de tradición grecolatina, sobre los que había modelos canónicos y doctrina preceptiva ${ }^{68}$. Pero a la vez transmiten un indefinición fronteriza por paridades heredadas de la más tradicional Poética: verso/ prosa y poesía/literatura, a las que se añade la recientísima objetividad/subjetividad, a mi juicio con origen en la clasicista percepción de la sátira como

${ }^{63}$ LÓPEZ BASTARÁN, Manuel. Retórica y Poética. Huesca: Vda. de Castanera, 1879, pp. 241-243; ESPANTALEÓN Y CARRILLO, Antonio. Tratado de Retórica y Poética. Madrid: Minuesa de los Ríos, 1881, pp. 196-198; MILEGO E INGLADA, Saturnino. Tratado de Literatura Preceptiva. Toledo: Imprenta de Fando y Hno., 1887, pp. 267-275.

${ }^{64}$ REVILLA, Manuel de la y ALCÁNTARA GARCÍA, Pedro. Principios Generales de Literatura. Madrid: Iravedra y Novo, 1877, p. 403. Sobre la sátira pp. 400-412.

65 ORTEGA Y FRÍAS, F. La escuela del poeta. Badajoz: Santamaría y Navarro, 1870, pp. 74-75; CAMPILLO Y CORREA, Narciso. Retórica y Poética o Literatura Preceptiva. Madrid: Segundo Martínez, 1872, pp. 388-390.

${ }^{66}$ BAQUERO ALMANSA, Andrés. Lecciones de Retórica y Poética. Murcia: Imprenta de las Provincias, 1897, p.188.

67 JUSTE E ISABA, Pedro. Literatura General. I. Madrid: Tipografía Reina, 1895, p. 240 .

${ }^{68}$ Siempre la novela en menor grado. Vid. GONZÁLEZ ALCÁZAR, Felipe. «Teorías sobre la novela en los preceptistas españoles del siglo XIX». Dicenda, 2005, 23, 109-124. 
expresión de un ideal moral divergente y enfrentado en contraste con la realidad circundante, viva y real, pero inasible y decepcionante ${ }^{69}$.

\section{ALGUNAS CONCLUSIONES}

Resulta consecuente con mis primeras palabras - y las prestadas de García Gual- el peculiar alojamiento de la sátira dentro de la estructura genérica impuesta por el triunfo del hegelianismo, más aún que su misma situación en el sistema general de la Preceptiva retórico-poética con toda su herencia doctrinal de modelo prestigioso a través de la satura y sus tres autores modélicos. Las fuerzas que operan internamente en la modernización del paradigma clasicista, en pugna por triunfar y oponer el suyo propio, no son capaces de liberar al pensamiento teórico-literario de la carga inmensa de la tipología tradicional. La sátira se encuentra a menudo en los límites, jugando y traspasando las fronteras de la rigidez normativa. Reconozcamos, sin embargo, que los autores más cercanos al clasicismo suelen acercarse con mayor libertad a la naturaleza de aquellos géneros no siempre canónicos, por atenuarse la presión preceptiva y liberarse así de la fijación en modelos opresivos de clara delimitación, como sucede con la tragedia o la epopeya. El asedio al acomodo satírico se produce desde un nivel pragmático, en cuanto se hallaban interesados los teóricos en el control sobre los rasgos que pudieran enfrentarse con manifestaciones y fines decorosos. Desde el punto de vista de la finalidad, baste volver los ojos al prudente e insistente consejo de tratados y manuales sobre la debida corrección de costumbres, conscientes de la utilidad del mensaje impositivo pero libre de fijación reglamentada ante la labilidad de la sátira.

Sin embargo, la presión sobre la nueva doctrina genérica impulsada por la escuela hegeliana busca elementos inalterables en todo modelo clasificado. La pérdida del valor de aquel sistema clasicista que permitió al satirógrafo ser, en cierto modo, un purgador y un corrector de la sociedad que reflejaban sus ataques, le convierte a lo largo del siglo XIX en un ser pasivo, un espectador que reacciona ante la incoherencia de una realidad que carece de sentido estético. No revela su sátira una verdad artificial, la verdad contenida en la Belleza, sino la objetividad del Mundo no ideal que aparece nítidamente ante los ojos del lector. En ese aspecto, el de portador de un claro mensaje acerca de que el Arte puede no ser manifestación de la Belleza, radican las reticencias de Hegel contra la satura y la reconsideración del estatuto formativo y

${ }^{69}$ Un único caso viene a divergir de todo lo anterior. Para Sánchez de Castro, op.cit. pp. 167-168 y 333-340, la Sátira pertenece ineludiblemente a lo subjetivo, ya que no representa al modelo de un género sino asunto y modo de todos los géneros. Como censura y burla de defectos humanos expresa claramente la subjetividad del poeta. Su fondo es totalmente lírico y su esquema el de la satura, verdadera composición didáctica que expresa artísticamente la intención burlesca. 
educativo que parecía formar parte de su idiosincrasia radical. Sin embargo, el mero intento de instalarse entre otras categorías estéticas hubiera bastado para plasmar en esta iniciativa filosófica un aspecto de modernización del modo satírico, mediante la ausencia o negación de Belleza en cuanto propósito central de tales obras literarias en un grado distanciador. Esta pretensión hubo de ser controlada, apenas nació, por la naturaleza calológica del Arte para el Idealismo y sus continuadores, para quienes no cabían categorías centrales como lo Feo, lo Grotesco o lo Absurdo.

Por otro lado, el modelo preceptivo viene a recoger en su seno, con naturalidad, la situación de la sátira entre las diversas formas que actúan como eslabones, como pegamento que mantiene cohesionadas las diferencias fundamentales entre actitudes líricas, épicas y dramáticas. La naturaleza de la sátira, así reconocido por algunos tratadistas, consistía en ausencia o multiplicidad de formas, lo que acrecentaba sus posibilidades en tanto género ario y en cuanto rasgo peculiar de casi todo posible género. Pero tampoco esta sugerencia, presente desde antiguo, pudo, entre las seguridades que pretendían ofrecerse a través de la tratadística clasicista, abrirse un camino con expectativas de generación de ideas más ajustadas a la literatura el uso de motivos y rasgos definitorios del Romanticismo y de la Modernidad: ya fueran el humor, la crítica o el mero interés en el realismo como motor de cambio estético-creativo.

Si la literatura podía abrirse a toda manifestación escrita con intención estética - casi cabría decir con elementos constructivos de elocución retórica-, en la que caben obras poéticas, oratorias y doctrinal-didácticas, los géneros poéticos exclusivos sólo se relacionan con la pura Belleza y la manifestación del absoluto en estos tratados imbuidos, como dijimos antes, de un hegelianismo domesticado que trae como consecuencia la perpetuación de la vieja filosofía de las Bellas Letras a las puertas del siglo XX.

Ya se defina género mixto, de transición o complejo, queda claro que el hibridismo que manifiestan estas nominaciones plantea el ejemplo más nítido de la inasibilidad satírica y de la presión inalterable de la Poética clasicista por la pureza dentro de sus propios límites. Los procesos comunicativos que impone, su capacidad para revestirse de las más diversas formas y de aparecer invasivamente en los textos más insospechados, determinaron que el lugar de la sátira en la Poética se desplazase hacia la expresividad artística frente al formalismo estructural. Y que ni uno ni otro lugar pueda considerarse definitivo ni estable.

Fecha de recepción: 24 de julio de 2007

Fecha de aceptación. 24 de marzo de 2008 